\title{
Implementasi Pemantauan Suhu Kelembaban serta Pengendali Penyiraman Tanaman secara Otomatis pada Greenhouse Berbasis Web
}

\author{
Lalu Rahmat Hidayat ${ }^{\star 1}$, Zamah Sari ${ }^{2}$, Fatimah Nursandi ${ }^{3}$ \\ 1,2,3Teknik Informatika/Universitas Muhammadiyah Malang \\ laluafkari31@gmail.com¹, zamahsari@umm.ac.id², fatimah.nursandi@umm.ac.id ${ }^{3}$
}

\begin{abstract}
Abstrak
Aglaonema merupakan tanaman hias daun yang memiliki nilai keindahan pada variasi daun, baik motif warna maupun bentuk daun. Aglaonema tumbuh pada suhu $24-27^{\circ} \mathrm{C}$ dan kelembaban $65-75 \%$, serta tidak terkena sinar matahari langsung. Untuk mendapatkan kondisi ideal maka aglaonema ditempatkan didalam sebuah greenhouse. Sehingga dirancanglah sebuah sistem yang dapat memantau suhu, kelembaban serta pengendalian penyiraman tanaman secara otomatis pada greenhouse. Adapun alat yang digunakan untuk merancang sistem ini adalah sensor DHT22, mikrokontroller Arduino uno, relay, selenoid valve, ethernet shield dan pompa air. Sensor ditempatkan pada 3 loakasi di dalam greenhouse yakni zona atap, zona dinding dan zona tanaman. Pemantauan dilakukan melalui web server dalam bentuk tabel dan grafik. Hasil pengujian didapatkan bahwa sistem ini dapat bekerja dengan baik. Dht22 dapat membaca suhu dan kelembaban dengan margin error dari pengukuran ini yakni suhu $0,41^{\circ} \mathrm{C}$ dan kelembaban 2,56\%. Pompa air bekerja dengan batasan yang telah ditentukan, ketika melebihi batas maka relay menyala dan pompa air bekerja. Hal ini sudah sesuai dengan yang diharapkan. Pengiriman data hasil sensor ke server dapat membaca dengan benar, hasil pengujian nilai sensor pada serial monitor dan di web server memiliki nilai yang sama, meskipun teradi delay. Web server dapat menampilkan data suhu dalam bentuk grafik dan tabel. Suhu dan kelembaban ideal berhasil berhasil dilakukan. Rata-rata suhu dan kelembaban ruangan sebelum menggunakan sistem yakni $30.2^{\circ} \mathrm{C}$ dan $56,86 \%$. Sedangkan rata-rata suhu dan kelembaban ruangan setelah menggunakan sistem yakni $27.85^{\circ} \mathrm{C}$ dan $73,99 \%$. Hal ini menunjukkan bahwa terjadi penurunan rata-rata suhu sebesar $2.35^{\circ} \mathrm{C}$ dan kenaikan kelembaban sebesar $17.13 \%$.
\end{abstract}

Kata Kunci: Aglaonema, Greenhouse, Arduino Uno, DHT22

\begin{abstract}
Aglaonema is a leaf ornamental plant that has a beauty value on the variation of leaves, both color and leaf shape motif. Aglaonema grows at $24-27^{\circ} \mathrm{C}$ and humidity $65-75 \%$, and it's not exposed to direct sunlight. To get ideal conditions aglaonema placed in a greenhouse. So designed a system that can monitor the temperature, humidity and control of plant watering automatically on the greenhouse. The tools used to design this system are DHT22 sensor, arduino uno microcontroller, relay, selenoid valve, ethernet shield and water pump. The sensors are placed in 3 loacations within the greenhouse in the roof zone, the wall zone and the plant zone. Monitoring is done through a web server in the form of tables and graphs. Test results found that this system can work well. Dht22 can read the temperature and humidity with the error margin of this measurement ie temperature of $0.41^{\circ} \mathrm{C}$ and humidity 2,56\%. The water pump works with a predetermined limit, when it exceeds the limit the relay lights up and the water pump works. This is as expected. Delivery of the sensor data to the server can read correctly, the test results of sensor values on the serial monitor and on the web server have the same value, although delay occurs. The web server can display temperature data in the form of graphs and tables. Ideal temperature and humidity successfully performed. Average temperature and humidity of the room before using the system that is $30.2^{\circ} \mathrm{C}$ and $56.86 \%$. While the average temperature and humidity of the room after using the system that is $27.85^{\circ} \mathrm{C}$ and $73.99 \%$. This shows that there is a decrease in the average temperature of $2.35^{\circ} \mathrm{C}$ and humidity increase of $17.13 \%$.
\end{abstract}

Keywords: Aglaonema, Greenhouse, Arduino Uno, DHT22 


\section{Pendahuluan}

Aglaonema (Sri Rejeki) adalah tanaman hias daun yang diartikan sebagai tanaman membawa keberuntungan. Aglaonema merupakan salah satu jenis tanaman hias yang memiliki nilai keindahan pada variasi daun, baik motif warna, bentuk dan ukuran [1]. Aglaonema dijuluki sang ratu daun [2], dikarenakan nilai jual tanaman tinggi, mulai dari puluhan ribu hingga ratusan ribu rupiah, tergantung pada kualitas daunnya [3]. Semakin banyak jumlah daun, semakin mahal pula nilai jualnya. Melihat prospek yang tinggi maka tak heran banyak membudidayakan tanaman ini [1]. Faktor yang harus diperhatikan dalam budidaya tanaman aglaonema adalah syarat tumbuhnya, yakni memperoleh pencahayaan yang baik karena aglaonema sangat peka terhadap cahaya. Jika sinar matahari mengenai aglaonema lebih dari 50\%, maka daunnya akan terbakar. Sedangkan suhu udara yang cocok untuk pertumbuhan aglaonema adalah $24^{\circ} \mathrm{C}-27^{\circ} \mathrm{C}$ pada siang hari dan $18^{\circ} \mathrm{C}-21^{\circ} \mathrm{C}$ pada malam hari. Sementara itu, kelembaban udara ideal bagi tanaman ini adalah 50\% - 75\%. Berdasarkan uraian tersebut maka dibutuhkan greenhouse sebagai naungan yang dapat memanipulasi pencahayaan, suhu dan kelembaban [4].

Greenhouse merupakan sebuah bangunan yang dibuat untuk menghindari dan memanipulasi kondisi lingkungan sesuai dengan yang dikehendaki dalam pemeliharaan tanaman [5]. Greenhouse adalah salah satu fasilitas kebutuhan mutlak dalam budidaya tanaman [6]. Penggunaan greenhouse dalam budidaya tanaman merupakan salah satu cara untuk memberikan lingkungan yang lebih baik bagi pertumbuhan tanaman [7], sehingga dapat dimungkinkan untuk dilakukannya modifikasi lingkungan sesuai dengan kebutuhan tanaman. Mitra Anggrek Indonesia merupakan salah satu pelaku usaha tanaman hias di Kota Wisata Batu yang membudidayakan tanaman aglaonema. Greenhouse yang dimiliki mitra anggrek indonesia memiliki struktur bangunan terbuat dari plastic yang dapat menyaring sinar matahari sehingga aglaonema tidak terkena cahaya matahari langsung. Akan tetapi, pada greenhouse ini, masih belum memiliki sistem pemantauan suhu dan kelembaban udara serta pengendali penyiraman secara otomatis. Oleh karenanya, diperlukan sebuah sistem pemantauan perubahan suhu, kelembaban udara dan sistem kendali penyiraman secara otomatis sehingga mempermudah pemilik greenhouse dalam proses budidaya tanaman aglaonema.

\section{Metode Penelitian}

Penelitian ini dilaksanakan berdasarkan permasalahan yang terjadi di Mitra Anggrek Indonesia. Mitra Anggrek Indonesia merupakan salah satu pelaku usaha tanaman hias yang membudidayakan tanaman aglaonema di sebuah greenhouse. Adapun permasalahan berkaitan dengan cara pemantauan suhu, kelembaban melalui komputer serta penyiraman secara otomatis. Ada beberapa tahapan yang dilakukan dalam menyelesaikan permasalahan tersebut yakni tahap persiapan penelitian, tahap perancangan sistem dan tahap implementasi.

\subsection{Tahap Persiapan Penelitian}

Tahap persiapan penelitian dilakukan untuk melakukan observasi, guna mengetahui kebutuhan-kebutuhan dalam menyelesaikan masalah pada greenhouse. Serta mengetahui berbagai data terkait suhu dan kelembaban. Berdasarkan tinjauan lapangan diketahui bahwa tanaman yang ada adalah 152 tanaman aglonema yang ditempatkan dalam sebuah greenhouse. Kemudian dilakukan pengamatan berkaitan dengan pola perubahan suhu, kelembaban didalam area greenhouse sehingga dapat mengetahui penempatan alat penyiraman agar suhu dan kelembaban stabil. Pengambilan data awal sebelum melakukan desain dan implementasi sistem yang dirancang yaitu dilakukan selama 3 hari. Berdasarkan data awal diketahui suhu rata-rata greenhouse pada siang hari yakni $28.5^{\circ} \mathrm{C}$ dan $56 \%$.

Beberapa kebutuhan yang diperlukan dalam membangun sistem berdasarkan observasi yakni sensor dht22 sebagai sensor suhu dan kelembaban, mikrokontroller Arduino uno sebagai otak program, Ethernet shield untuk menghubungkan Arduino dengan jaringan, relay sebagai saklar on/off, pompa air, dan laptop sebagai server.

\subsection{Tahap Analisa Kebutuhan Sistem}

Tahap ini dilakukan untuk mengetahui komponen yang dibutuhkan dalam membangun sistem. Adapun beberapa kebutuhan dalam membangun sistem ini terdiri dari kebutuhan perangkat keras dan kebutuhan perangkat lunak.

REPOSITOR, Vol. 2, No. 4, April 2020: 403-414 


\subsubsection{Kebutuhan Perangkat Keras}

Beberapa kebutuhan perangkat keras yang diperlukan dalam membangun sistem berdasarkan observasi.

1. Arduino Uno

Arduino uno merupakan sebuah board mikrokontroller yang menggunakan chip ATMEGA328P. Arduino uno memiliki 14 pin digital input/output, sebuah koneksi USB, sebuah power jack, sebuah ICSP header dan tombol reset. Gambar 1 memperlihatkan perangkat arduino uno [8].

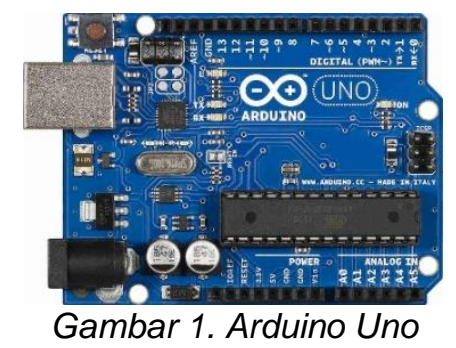

\section{Sensor DHT22}

Sensor DHT22 merupakan sensor dengan kalibrasi yang menerapkan teknik pengumpulan sinyal digital dan teknologi pengindraan kelembaban. sensor ini memiliki keandalan dan stabilitas yang baik dikarenakan dapat terhubung dengan 8 bit chip tunggal komputer [9]. Gambar 2 menunjukkan sensor DHT22.
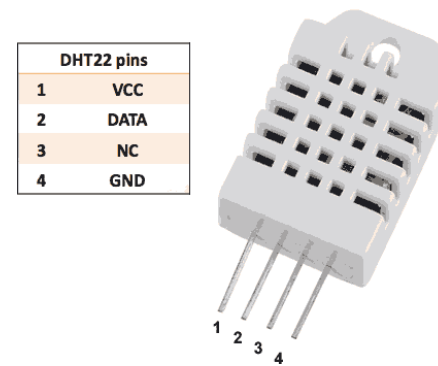

Gambar 2. Sensor DHT22

\section{Ethernet Shield}

Ethernet shield pada Gambar 3 merupakan modul yang memungkinkan Arduino terhubung dengan internet dalam hitungan detik. Ethernet shield berbasis cip Ethernet wiznet W5100. Wiznet W5100 menyediakan (IP) yang mampu menyediakan komunikasi TCP dan UDP. Supaya dapat menggunakan Ethernet shield pada penulian sketch atau kode pada Arduino IDE dibutuhkan library Ethernet shield agar dapat dikendali oleh board Arduino [10].

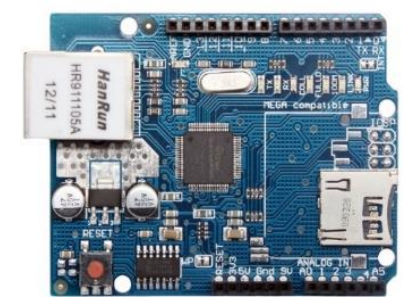

Gambar 3. Ethernet Shield

\section{Relay}

Relay pada Gambar 4 adalah komponen elektronika berupa saklar elektronik yang digerakkan oleh arus listrik. Secara prinsip, relay merupakan tuas saklar dengan lilitan kawat pada batang besi di dekatnya. Ketika solenoid dialiri arus listrik, tuas akan tertarik karena adanya gaya magnet yang terjadi pada solenoid sehingga kontak saklar akan menutup. Pada saat arus 
dihentikan, gaya magnet akan hilang, tuas akan kembali ke posisi semula dan kontak saklar kembali terbuka [11].

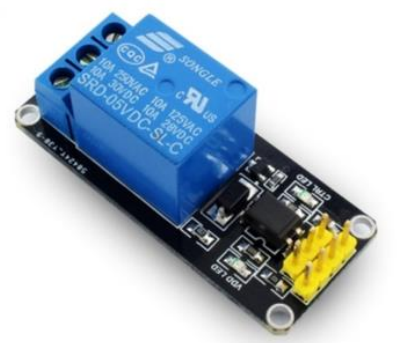

Gambar 4 Relay

5. Selenoid Valve

Selenoid valve Gambar 5 merupakan katup yang dikendalikan dengan arus listrik baik AC maupun DC melalui kumparan. Solenoid valve ini merupakan elemen kontrol yang paling sering digunakan dalam sistem fluida. Solenoid valve akan bekerja bila kumparan mendapatkan tegangan arus listrik yang sesuai dengan tegangan kerja sehingga menyebabkan sebuah pin akan tertarik karena gaya magnet yang dihasilkan dari kumparan selenoida tersebut [12].

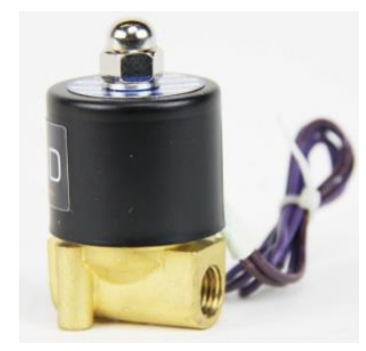

Gambar 5. Selenoid valve

\subsubsection{Kebutuhan Perangkat Lunak}

Beberapa kebutuhan perangkat lunak dalam membangun sistem ini diantaranya:

1. Software Arduino

Arduino menggunakan Bahasa pemrograman $\mathrm{C}++$ yang telah dipermudah melalui library. Arduino menggunakan software processing yang digunakan untuk menulis program kedalam Arduino. Processing sendiri merupakan penggabungan antara Bahasa $\mathrm{C}_{++}$dan java. Software Arduino ini dapat di install diberbagai operating system atau OS sperert: windows, linux, Mac OS. Software IDE Arduino terdiri dari editor, compiler dan upload [13].

2. Web Server

Web server merupakan sebuah perangkat lunak dalam server yang berfungsi menerima permintaan (request) berupa halaman web melalui HTTP atau HTTPS dari klien yang dikenal dengan web browser dan mengirimkan kembali (response) hasilnya dalam bentuk halaman web yang umumnya berbentuk dokumen HTML. Web server yang digunakan pada penelitian ini adalah apache web server karena bersifat open source, lebih detail, pengaturan relative lebih mudah, extensible.

HTTP adalah suatu metode yang digunakan untuk transger suatu informasi melalui world wide web. HTTP merupakan protokol yang digunakan untuk request/response antara client dan server. Bentuk dari client adalah web browser dan bentuk lain yang direferensi sebagai user agent. Tujuan server yaitu menyimpan dan membuat sumber daya seperti file html dan file gambar yang disebut origin server [14].

\subsection{Tahap Perancangan Sistem}

Sistem pemantauan suhu, kelembaban serta pengendalian penyiraman tanaman secara otomatis merupakan sebuah sistem terintegrasi yang terhubung dengan jaringan sebagai proses pemantauan perubahan suhu dan kelembaban udara serta sebagai pengendali penyiraman

REPOSITOR, Vol. 2, No. 4, April 2020: 403-414 
tanaman secara otomatis ketika kondisi suhu dan kelembaban berada dalam batas yang tidak normal.

Sensor dht22 akan membaca nilai suhu dan kelembaban udara untuk diproses di mikrokontroller. Jika nilai yang dibaca sensor dht22 melebihi batas normal maka mikrokontroller akan mengirimkan sinyal ke relay untuk mengaktifkat selenoid valve sehingga alat pengendali penyiraman tanaman akan bekerja. Seluruh data hasil sensor akan dikirim ke server menggunakan ethernet shield dengan jaringan lan.

Data yang dikirim akan disimpan kedalam database dengan memanfaatkan php sebagai penghubung. Kemudian data tersebut akan ditampilkan dalam website berupa tabel dan grafik informasi terkait perubahan suhu dan kelembaban pada greenhouse. Gambar 6 menampilkan diagram blok sistem.

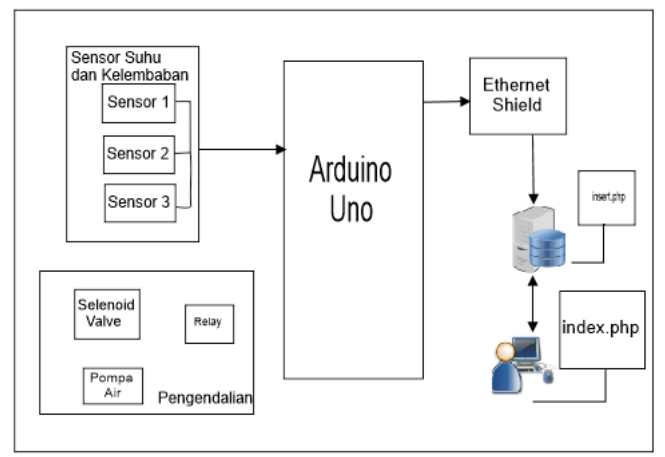

Gambar 6. Blok Desain Sistem

\section{Hasil Penelitian dan Pembahasan}

\subsection{Implementasi Sistem}

Tahap ini perangkat keras sudah terpasang. Sensor DHT22 dihubungkan dengan modul arduino uno. Kontak relay dihubungkan dengan selenoid valve, sedangkan pin-pin pada relay dihubungkan dengan arduino uno. Kemudian Ethernet shield dihubungkan ke server. pin modul pada Arduino untuk mendapatkan perintah menghidupkan pompa air sehingga keseluruhan sistem dapat terhubung serta mampu bekerja dengan baik untuk memantau serta mengendalikan penyiraman otomatis pada tanaman aglaonema. Adapun cara kerjanya yakni Sensor dht22 akan membaca nilai suhu dan kelembaban udara untuk diproses di mikrokontroller. Jika nilai yang dibaca sensor dht22 melebihi batas normal maka mikrokontroller akan mengirimkan sinyal ke relay untuk mengaktifkat selenoid valve sehingga alat pengendali penyiraman tanaman akan bekerja. Seluruh data hasil sensor akan dikirim ke server menggunakan ethernet shield dengan jaringan lan. Data yang dikirim akan disimpan kedalam database dengan memanfaatkan php sebagai penghubung. Kemudian data tersebut akan ditampilkan dalam website berupa tabel dan grafik informasi terkait perubahan suhu dan kelembaban pada greenhouse.

Penempatan sensor dibagi menjadi 3 zona diantaranya zona atap, zona dinding, zona tanaman. Hal ini didasari dari hasil observasi yang telah dilakukan pada bangunan greenhouse, bahwa pada zona tersebut ditemukan suhu dan kelembaban ruangan yang berbeda-beda. Gambar 7 memperlihatkan penempatan sensor pada bangunan greenhouse. Sedangkan gambar 8 memperlihatkan proses instalasi pemasangan sensor.

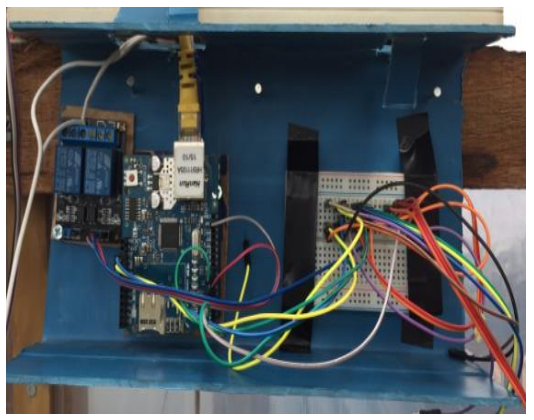

Gambar 7. Rangkaian Hardware 


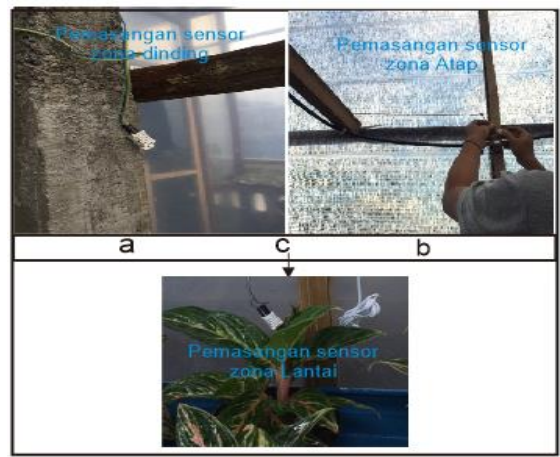

Gambar 8. Instalasi Pemasangan Sensor, a). Zona Dinding,

b). Zona Atap, c). Zona Tanaman

\subsection{Pengujian Sistem}

Tahap ini dibahas terkait dengan pengujian terhadap sistem yang telah dibuat. Komponen diuji secara terpisah dan diuji secara keseluruhan sehingga dapat dipastikan sistem berjalan dengan baik.

\subsubsection{Pengujian Pengiriman Data Sensor ke Web Server}

Tahap ini membahas terkait dengan pengiriman data hasil sensor ke web server. Data hasil sensor dikirim ke database untuk disimpan, kemudian ditampilkan dalam web server melalui browser, seperti terlihat pada Gambar 9.

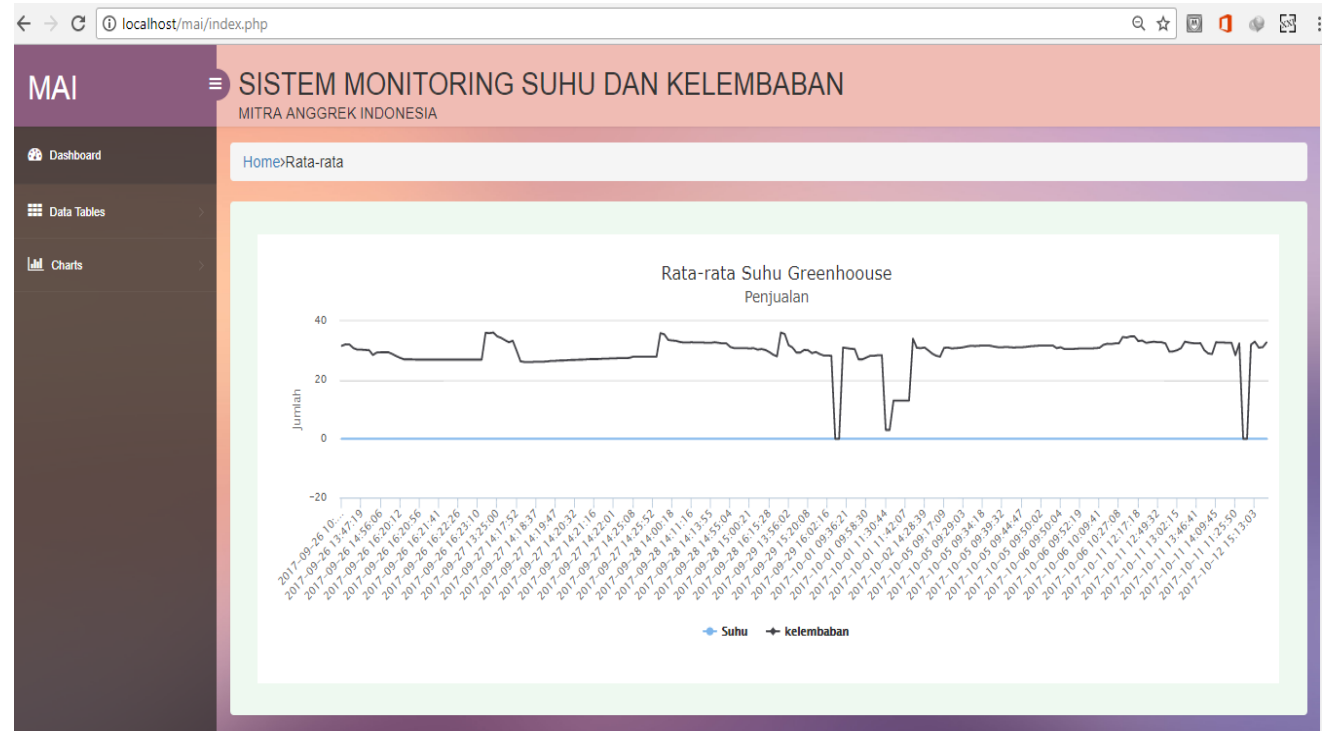

Gambar 9. Tampilan Web Server

Berdasarkan gambar 9 diatas terlihat bahwa data hasil sensor dapat ditampilkan pada web server dengan baik. Ini membuktikan bahwa sistem telah bekerja sesuai dengan rancangan yang telah dirancang pada sebelumnya.

\subsubsection{Pengujian Suhu dan Kelembaban}

Pengujian suhu dilakukan dengan membandingkan data sensor suhu dengan humidity temperature clock (HTC 2). Pengujian dilakukan dengan mengukur suhu greenhouse dibeberapa zona. Pengambilan data dilakukan sebanyak 10 kali pada masing-masing zona. Data yang dihasilkan dimasukkan kedalam tabel untuk dicari margin error terhadap suhu dan kelembaban. Kemudian dari margin error tersebut akan diketahui rata-rata error terhadap hasil sensor menggunakan sensor dht22 dan htc2. Tabel 1, Tabel 2 dan Tabel 3 menunjukkan hasil pengujian sensor dht22 dengan HTC2. 
Tabel 1. Pengujian Sensor Suhu Zona Tanaman

\begin{tabular}{|c|c|c|c|c|c|c|}
\hline \multirow{2}{*}{ WAKTU } & \multicolumn{2}{|c|}{ HTC 22} & \multicolumn{2}{|c|}{ DHT 22} & \multirow{2}{*}{ Error $\left({ }^{\circ} \mathrm{C}\right)$} & \multirow{2}{*}{$\begin{array}{l}\text { Error } \\
(\%)\end{array}$} \\
\hline & Temp & Hum & Temp & Hum & & \\
\hline 11:20 & 29 & 56 & 28.6 & 58.8 & 0.4 & 2.8 \\
\hline $13: 47$ & 29.5 & 57 & 28.9 & 59.3 & 0.6 & 2.3 \\
\hline $14: 05$ & 28.5 & 60 & 28.9 & 58.7 & 0.4 & 1.3 \\
\hline $14: 22$ & 28.5 & 60 & 27.9 & 63.3 & 0.6 & 3.3 \\
\hline 14:39 & 28.7 & 61 & 28.4 & 61.6 & 0.3 & 0.6 \\
\hline $14: 59$ & 28.6 & 59 & 28.5 & 62.5 & 0.1 & 3.5 \\
\hline $15: 12$ & 28.8 & 60 & 28.5 & 60.2 & 0.3 & 0.2 \\
\hline $15: 29$ & 28.5 & 64 & 28.6 & 60.7 & 0.1 & 3.3 \\
\hline $15: 46$ & 27.9 & 66 & 28 & 66 & 0.1 & 0 \\
\hline $16: 03$ & 27.4 & 71 & 27.5 & 68.5 & 0.1 & 2.5 \\
\hline \multicolumn{5}{|c|}{ Rata-rata } & 0.3 & 1.98 \\
\hline
\end{tabular}

Tabel 2. Pengujian Sensor Suhu Zona Dinding

\begin{tabular}{|c|c|c|c|c|c|c|}
\hline \multirow[b]{2}{*}{ WAKTU } & \multicolumn{2}{|c|}{ HTC 2} & \multicolumn{2}{|c|}{ DHT 22} & \multirow{2}{*}{ Error $\left({ }^{\circ} \mathrm{C}\right)$} & \multirow{2}{*}{$\begin{array}{c}\text { Error } \\
(\%)\end{array}$} \\
\hline & Temp & Hum & Temp & Hum & & \\
\hline $13: 22$ & 34.3 & 41 & 33.7 & 46.2 & 0.6 & 5.2 \\
\hline 13:39 & 32.4 & 47 & 33.5 & 46.9 & 1.1 & 0.1 \\
\hline 13:56 & 31.5 & 52 & 30.9 & 52.7 & 0.6 & 0.7 \\
\hline $14: 12$ & 30.5 & 54 & 30.5 & 53 & 0 & 1 \\
\hline $14: 29$ & 29.9 & 60 & 29.3 & 58.3 & 0.6 & 1.7 \\
\hline $14: 46$ & 30.2 & 57 & 29 & 62.3 & 1.2 & 5.3 \\
\hline $15: 03$ & 30.2 & 57 & 29.7 & 59.5 & 0.5 & 2.5 \\
\hline $15: 19$ & 29.8 & 56 & 29.6 & 59.6 & 0.2 & 3.6 \\
\hline $15: 36$ & 29.8 & 57 & 28.8 & 59.3 & 1 & 2.3 \\
\hline $15: 53$ & 29.5 & 64 & 29.1 & 59.3 & 0.4 & 4.7 \\
\hline \multicolumn{5}{|c|}{ Rata-Rata } & 0.56 & 2.72 \\
\hline
\end{tabular}

Tabel 3. Pengujian Sensor Suhu Zona Atap

\begin{tabular}{|c|c|c|c|c|c|c|}
\hline \multirow{2}{*}{ WAKTU } & \multicolumn{2}{|c|}{ HTC 2} & \multicolumn{2}{|c|}{ DTC 22} & \multirow{2}{*}{$\begin{array}{l}\text { Error } \\
\left({ }^{\circ} \mathrm{C}\right)\end{array}$} & \multirow{2}{*}{$\begin{array}{c}\text { Error } \\
(\%)\end{array}$} \\
\hline & Temp & Hum & Temp & Hum & & \\
\hline 13.37 & 34 & 37 & 37.5 & 35 & 3.5 & 2 \\
\hline 13:50 & 33.4 & 37 & 35.5 & 40.3 & 2.1 & 3.3 \\
\hline $14: 34$ & 32.2 & 40 & 32.8 & 43.4 & 0.6 & 3.4 \\
\hline 14:51 & 31.2 & 54 & 32.4 & 52.3 & 1.2 & 1.7 \\
\hline 15:08 & 30.7 & 54 & 30.8 & 58.1 & 0.1 & 4.1 \\
\hline $15: 25$ & 30.5 & 55 & 30.3 & 56.7 & 0.2 & 1.7 \\
\hline $15: 41$ & 30.3 & 54 & 30.5 & 58.7 & 0.2 & 4.7 \\
\hline $16: 58$ & 29.8 & 58 & 30.2 & 57 & 0.4 & 1 \\
\hline 16:15 & 29.1 & 60 & 29.5 & 62 & 0.4 & 2 \\
\hline $16: 24$ & 28.6 & 61 & 28.6 & 65.8 & 0 & 4.8 \\
\hline \multicolumn{5}{|c|}{ D } & 0.38 & 2.92 \\
\hline
\end{tabular}

Tabel-tabel diatas memperlihatkan bahwa pada masing-masing zona ditemukan terjadinya error. Tabel 1 memperlihatkan pada zona tanaman rata-rata error dari hasil pengukurannya yakni suhu $0.3^{\circ} \mathrm{C}$ dan kelembaban $1.98 \%$. Sedangkan zona dinding pada tabel 2 diketahui rata-rata kesalahan pengukuran suhu $0.56^{\circ} \mathrm{C}$ dan kelembaban $2.72 \%$. Kemudian pada zona atap ditemukan rata-rata kesalahan suhu $0.38^{\circ} \mathrm{C}$ dan kelembaban $2.92 \%$. Setelah itu, rata-rata suhu dan kelembaban dari ketiga zona tersebut dijumlahkan dan dibagi tiga, untuk mengetahui ratarata kesalahan pengukuran yang terjadi didalam greenhouse. Sehingga ditemukan kesalahan rata-rata suhu $0.41^{\circ} \mathrm{C}$ dan kelembaban $2.56 \%$.

Berdasarkan hasil pengujian suhu menggunakan sensor dht22 yang dibandingkan dengan HTC 2 pada Tabel 1, Tabel 2 dan Tabel 3, disimpulkan bahwa suhu dan kelembaban yang terukur dari sensor dht22 mendekati suhu terukur pada HTC2. 


\subsubsection{Pengujian Pengendalian Penyiraman secara Otomatis}

Pengujian pengendalian dilakukan setelah seluruh komponen yang ada dan saling terhubung. Pengujian dilakukan untuk mengetahui kinerja komponen secara keseluruhan dengan tujuan sistem yang dibangun telah sesuai dengan perancangan sistem. Pengujian ini meliputi pengujian pompa air dan pengujian waktu yang dibutuhkan untuk dapat terhubung ke jaringan.

Pengujian pompa air dilakukan dengan memberikan perlakuan pada suhu dan kelembaban. Batasan yang diberikan yakni suhu $27^{\circ} \mathrm{C}$ dan kelembaban $65 \%$. dimana kondisi ketika nilai suhu $<27^{\circ} \mathrm{C}$ dan/atau kelembaban $>65 \%$ pompa air mati, dan ketika kondisi suhu $>27^{\circ} \mathrm{C}$ dan/atau kelembaban $<65 \%$ pompa air menyala. Tabel 4 memperlihatkan hasil pengujian penyiraman otomatis.

Tabel 4. Pengujian sistem keseluruhan Pompa Air

\begin{tabular}{|c|c|c|c|c|c|c|c|c|c|}
\hline \multirow{2}{*}{ Waktu } & \multicolumn{2}{|c|}{ Zona Atap } & \multicolumn{2}{|c|}{ Zona tanaman } & \multicolumn{2}{|c|}{ Zona Dinding } & \multirow{2}{*}{$\begin{array}{c}\text { Rata - } \\
\text { Rata } \\
\text { Temp } \\
\left({ }^{0} \mathrm{C}\right)\end{array}$} & \multirow{2}{*}{$\begin{array}{c}\begin{array}{c}\text { Rata- } \\
\text { Rata }\end{array} \\
\text { Hum (\%) }\end{array}$} & \multirow{2}{*}{$\begin{array}{l}\text { Fogging } \\
\text { Machine }\end{array}$} \\
\hline & $\begin{array}{l}\text { Temp } \\
\left({ }^{\circ} \mathrm{C}\right)\end{array}$ & $\begin{array}{c}\text { Hum } \\
(\%)\end{array}$ & $\begin{array}{l}\text { Temp } \\
\left({ }^{0} \mathrm{C}\right)\end{array}$ & $\begin{array}{c}\text { Hum } \\
(\%)\end{array}$ & $\begin{array}{l}\text { Temp } \\
\left({ }^{\circ} \mathrm{C}\right)\end{array}$ & $\begin{array}{c}\text { Hum } \\
(\%)\end{array}$ & & & \\
\hline $12: 17: 18$ & 33.2 & 47.3 & 25 & 99.9 & 27.7 & 88.3 & 28.6 & 78.5 & On \\
\hline $12: 32: 22$ & 33.4 & 55.1 & 24 & 99.9 & 26.9 & 96.4 & 28.1 & 83.8 & On \\
\hline $12: 47: 26$ & 32.6 & 44 & 23.9 & 99.9 & 29.7 & 63 & 28.7 & 68.9 & On \\
\hline 13:01:12 & 29.7 & 55.8 & 22.5 & 99.9 & 23.6 & 99.9 & 25.2 & 85.2 & Off \\
\hline $13: 15: 45$ & 30.8 & 49.1 & 22.8 & 99.9 & 24.3 & 99.9 & 25.9 & 82.9 & Off \\
\hline $13: 30: 48$ & 33 & 41.8 & 26.1 & 99.9 & 30.9 & 58.6 & 30 & 66.7 & On \\
\hline $13: 45: 52$ & 32.7 & 38.9 & 29 & 95.5 & 31.1 & 51.6 & 30.9 & 62 & On \\
\hline $14: 07: 17$ & 28.8 & 57.3 & 21.8 & 99.9 & 24.3 & 99.9 & 24.9 & 85.7 & Off \\
\hline 14:10:16 & 32.7 & 38.8 & 24.9 & 99.9 & 30.3 & 55.5 & 29.3 & 64.7 & On \\
\hline $14: 25: 50$ & 28.4 & 38.6 & 25.2 & 99.9 & 27.3 & 57.2 & 26.9 & 65.2 & Off \\
\hline
\end{tabular}

Berdasarkan Tabel 4 menunjukkan hasil pengujian pengendalian penyiraman dapat bekerja dengan baik sesuai dengan yang diharapkan.

Tabel 5. Pengujian Waktu dan Data Hasil di Monitor Arduino dan Server

\begin{tabular}{cccccccc}
\hline \multicolumn{7}{c}{ Zona Atap - 05 Oktober 2017 } \\
\cline { 1 - 5 } No & Waktu & \multicolumn{2}{c}{ Serial Monitor } & \multicolumn{2}{c}{ Server } & & \\
\cline { 3 - 6 } & & $\begin{array}{c}\text { Temp } \\
\left({ }^{0} \mathrm{C}\right)\end{array}$ & $\begin{array}{c}\text { Hum } \\
(\%)\end{array}$ & $\begin{array}{c}\text { Temp } \\
\left({ }^{\circ} \mathrm{C}\right)\end{array}$ & $\begin{array}{c}\text { Hum } \\
(\%)\end{array}$ & Delay & Ket \\
\hline 1 & $9: 24: 51$ & 31 & 60.9 & 31 & 60.9 & 0 & Terkirim \\
2 & $9: 25: 54$ & 30.7 & 61.1 & 30.7 & 61.1 & 0 & Terkirim \\
3 & $9: 26: 57$ & 30.8 & 60.1 & 30.8 & 60.1 & 0 & Terkirim \\
4 & $9: 28: 00$ & 30.9 & 59.8 & 30.9 & 59.8 & 0 & Terkirim \\
5 & $9: 29: 03$ & 31.1 & 58.9 & 31.1 & 58.9 & 0 & Terkirim \\
6 & $9: 30: 06$ & 31.4 & 58.2 & 31.4 & 58.2 & 0 & Terkirim \\
7 & $9: 31: 09$ & 31.6 & 57.7 & 31.6 & 57.7 & 0 & Terkirim \\
8 & $9: 32: 12$ & 31.5 & 57.9 & 31.5 & 57.9 & 0 & Terkirim \\
9 & $9: 33: 15$ & 31.6 & 58 & 31.6 & 58 & 0 & Terkirim \\
10 & $9: 34: 18$ & 31.7 & 57.7 & 31.7 & 57.7 & 0 & Terkirim \\
11 & $9: 35: 21$ & 31.7 & 57.9 & 31.7 & 57.9 & 0 & Terkirim \\
12 & $9: 36: 23$ & 31.6 & 57.7 & 31.6 & 57.7 & 1 & Terkirim \\
13 & $9: 37: 26$ & 31.3 & 58 & 31.3 & 58 & 0 & Terkirim \\
14 & $9: 38: 29$ & 31.1 & 58.3 & 31.1 & 58.3 & 0 & Terkirim \\
15 & $9: 39: 32$ & 31.1 & 58.6 & 31.1 & 58.6 & 0 & Terkirim \\
\hline
\end{tabular}

Berdasarkan Tabel 5 menunjukkan bahwa data yang dikirim oleh sensor dapat diterima dengan baik oleh server. Pengambilan data dilakukan sebanyak 15 kali dengan interval 63 detik. Berdasarkan hasil pengambilan data terlihat bahwa waktu pengiriman data ke server tepat sesuai dengan waktu yang ditentuka, namun pada pengujian no 12 terjadi delay 1 detik. 


\subsection{Analisa Hasil Pengujian}

Analisa hasil pengujian dilakukan untuk menganalisa sistem yang telah dibuat. Analisa hasil pengujian dilakukan dengan 2 tahap antara lain:

\section{Analisa Hasil Penyiraman Secara Manual dengan Penyiraman Menggunakan Sistem Otomatisasi}

Analisa hasil dilakukan agar mengetahui efektifitas antara hasil pengairan secara manual dengan pengairan yang sudah menerapkan sistem otomatisasi. Pengambilan data dilakukan dua tahap yakni pengambilan data sebelum menerapkan sistem dan setelah menerapkan sistem. Setelah pengambilan data dilakukan, selanjutnya data dimasukkan kedalam tabel kemudian dicari rata-rata suhu dan kelembaban dari seluruh zona. Setelah itu dihitung rata-rata suhu dan kelembaban ruangan pada greenhouse. Table 6 dan 7 menunjukkan hasil pengambilan data yang telah dilakukan

Tabel 6. Sebelum Menggunakan Sistem

\begin{tabular}{|c|c|c|c|c|c|c|c|}
\hline \multirow{2}{*}{ Data } & \multicolumn{5}{|c|}{ Zona Atap Zona Tanaman Zona Dinding } & \multirow{2}{*}{$\begin{array}{l}\text { Rata- } \\
\text { Rata } \\
\text { Temp } \\
\left({ }^{\circ} \mathrm{C}\right)\end{array}$} & \multirow{2}{*}{$\begin{array}{c}\text { Rata - } \\
\text { Rata } \\
\begin{array}{c}\text { Hum } \\
(\%)\end{array}\end{array}$} \\
\hline & $\begin{array}{l}\text { Temp Hum } \\
\left({ }^{0} \mathrm{C}\right) \quad(\%)\end{array}$ & $\begin{array}{l}\text { Temp } \\
\left({ }^{\circ} \mathrm{C}\right)\end{array}$ & $\begin{array}{c}\text { Hum } \\
(\%)\end{array}$ & $\begin{array}{c}\text { Temp } \\
\left({ }^{\circ} \mathrm{C}\right)\end{array}$ & $\begin{array}{c}\text { Hum } \\
(\%)\end{array}$ & & \\
\hline 1 & 28.658 .8 & 33.7 & 46.2 & 37.5 & 35 & 33.26 & 46.66 \\
\hline 2 & 28.959 .3 & 33 & & & 40.3 & 32.63 & 48.83 \\
\hline 3 & 28.958 .7 & & & & & 30.86 & 51.6 \\
\hline 4 & 27.963 .3 & 30 & & & 3 & 30.26 & 56.2 \\
\hline 5 & 28.46 & 29 & & & .1 & 29.5 & 59.33 \\
\hline 6 & $28.56 ?$ & & & & .7 & 29.26 & 60.5 \\
\hline 7 & 28.560 & & & & 58.7 & 29.56 & 59.46 \\
\hline 8 & $28.6 \quad 60.7$ & 29 & & 30 & & 29.46 & 59.1 \\
\hline 9 & 28 & 28. & & 29.5 & $c$ & 28.76 & 62.43 \\
\hline 10 & 27.568 .5 & 29.1 & 59.3 & 28.6 & 65.8 & 28.4 & 64.53 \\
\hline \multicolumn{6}{|c|}{ lata - Rata } & 30.2 & 56.86 \\
\hline
\end{tabular}

\begin{tabular}{|c|c|c|c|c|c|c|c|c|}
\hline \multirow[b]{2}{*}{ Data } & \multicolumn{2}{|c|}{ Zona Atap } & \multicolumn{4}{|c|}{ Zona tanaman Zona Dindin } & \multirow{2}{*}{$\begin{array}{c}\text { Rata - } \\
\text { Rata } \\
\text { Temp } \\
\left({ }^{\circ} \mathrm{C}\right)\end{array}$} & \multirow{2}{*}{$\begin{array}{c}\text { Rata - } \\
\text { Rata } \\
\text { Hum (\%) }\end{array}$} \\
\hline & $\begin{array}{l}\text { Temp } \\
\left({ }^{0} \mathrm{C}\right)\end{array}$ & & $\begin{array}{l}\text { Temp } \\
\left({ }^{0} \mathrm{C}\right)\end{array}$ & $\begin{aligned} \text { Hum } \\
(\%)\end{aligned}$ & $\begin{array}{l}\text { Temp } \\
\left({ }^{0} \mathrm{C}\right)\end{array}$ & $\begin{array}{c}\text { Humi } \\
(\%)\end{array}$ & & \\
\hline 1 & 33.2 & 47.3 & 25 & 99.9 & 27.7 & 88.3 & 28.6 & 78.5 \\
\hline 2 & 33.4 & 55 & 24 & 99.9 & 26.9 & 96.4 & 28.1 & 31 \\
\hline 3 & 32.6 & 44 & 23.9 & 99.9 & 29.7 & 33 & 28.7 & 6 \\
\hline 4 & 29.7 & 55.8 & 22.5 & 99.9 & 23.6 & 99.9 & 25.2 & 85.23 \\
\hline 5 & 30.8 & 49.1 & 22.8 & 99.9 & 24.3 & 99.9 & 25.9 & 82.94 \\
\hline 6 & 33 & 41.8 & 26.1 & 99.9 & 30.9 & 58.6 & 30 & 66.75 \\
\hline 7 & 32.7 & 38.9 & 29 & 95.5 & 31.1 & 51.6 & 30.9 & 625 \\
\hline 8 & 28.8 & 57.3 & 21.8 & 99.9 & 24.3 & 99.9 & 24.9 & 85.76 \\
\hline 9 & 32.7 & 38.8 & 24.9 & 99.9 & 30.3 & 55.5 & 29.3 & 64.77 \\
\hline 10 & 28.4 & 38.6 & 25.2 & 99.9 & 27.3 & 57.2 & 26.9 & 65.28 \\
\hline & & & & & & & 27.85 & 73.99 \\
\hline
\end{tabular}

Berdasarkan Tabel 6 diketahui rata-rata suhu dan kelembaban ruangan sebelum menggunakan sistem yakni $30.2^{\circ} \mathrm{C}$ dan $56,86 \%$. Sedangkan Tabel 7 menunjukkan rata-rata suhu dan kelembaban ruangan setelah menggunakan sistem yakni $27.85^{\circ} \mathrm{C}$ dan $73,99 \%$. Hasil pengujian ini mampu menurunkan suhu mendekati suhu ideal yang dipertahankan yakni $24^{\circ} \mathrm{C}$ $27^{\circ} \mathrm{C}$. Sedangkan untuk kelembaban sudah sesuai dengan kondisi ideal yakni $65 \%-75 \%$. Selain itu, hasil pengujian menunjukkan bahwa terjadi penurunan rata-rata suhu sebesar $2.35^{\circ} \mathrm{C}$ dan kenaikan kelembaban sebesar $17.13 \%$. 
Selain ditunjukkan dalam bentuk tabel, analisa perbandingan suhu dan kelembaban ditampilkan dalam bentuk grafik sehingga mempermudah identifikasi. Gambar 10 dan Gambar 11 merupakan grafik perbandingan suhu dan kelembaban.

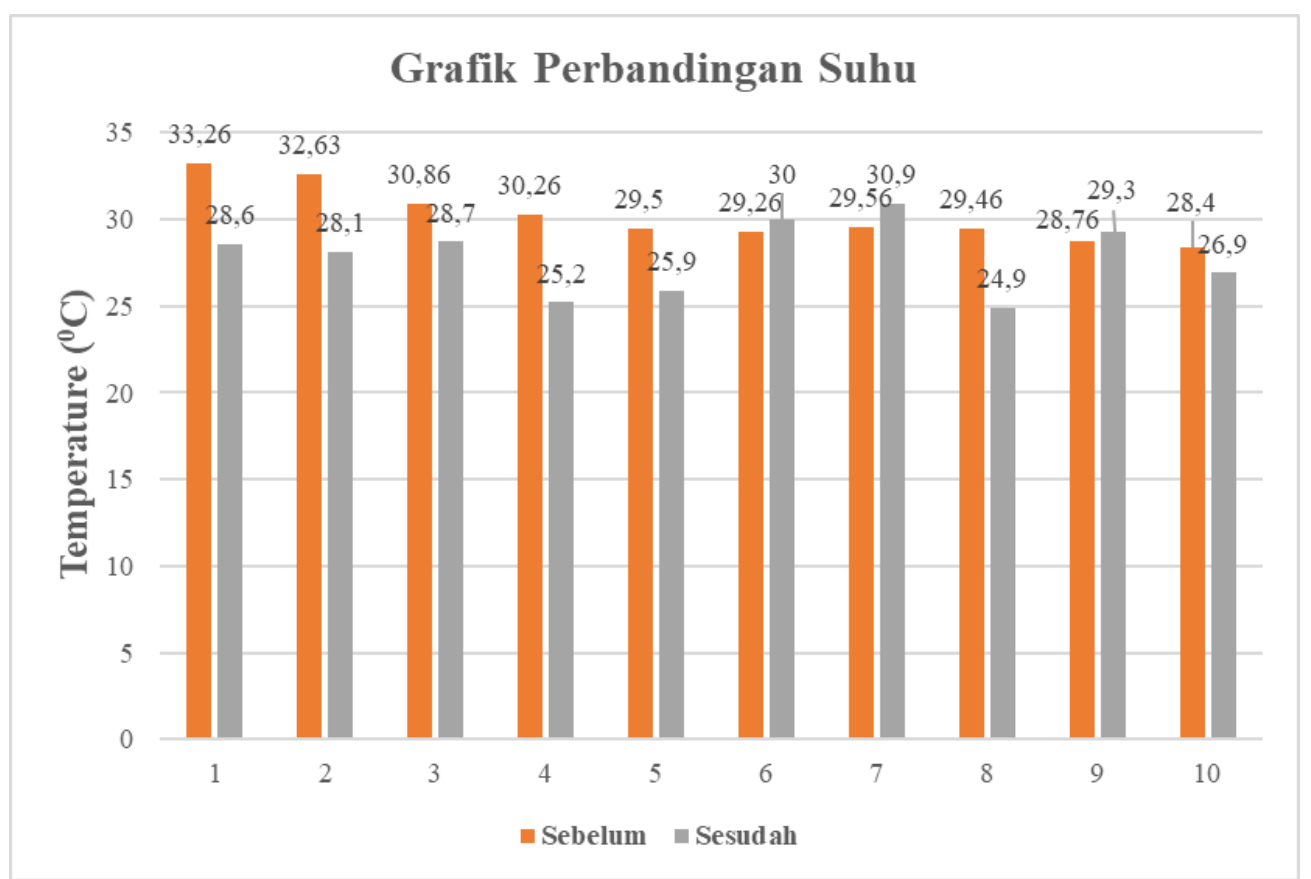

Gambar 10. Perbandingan Suhu

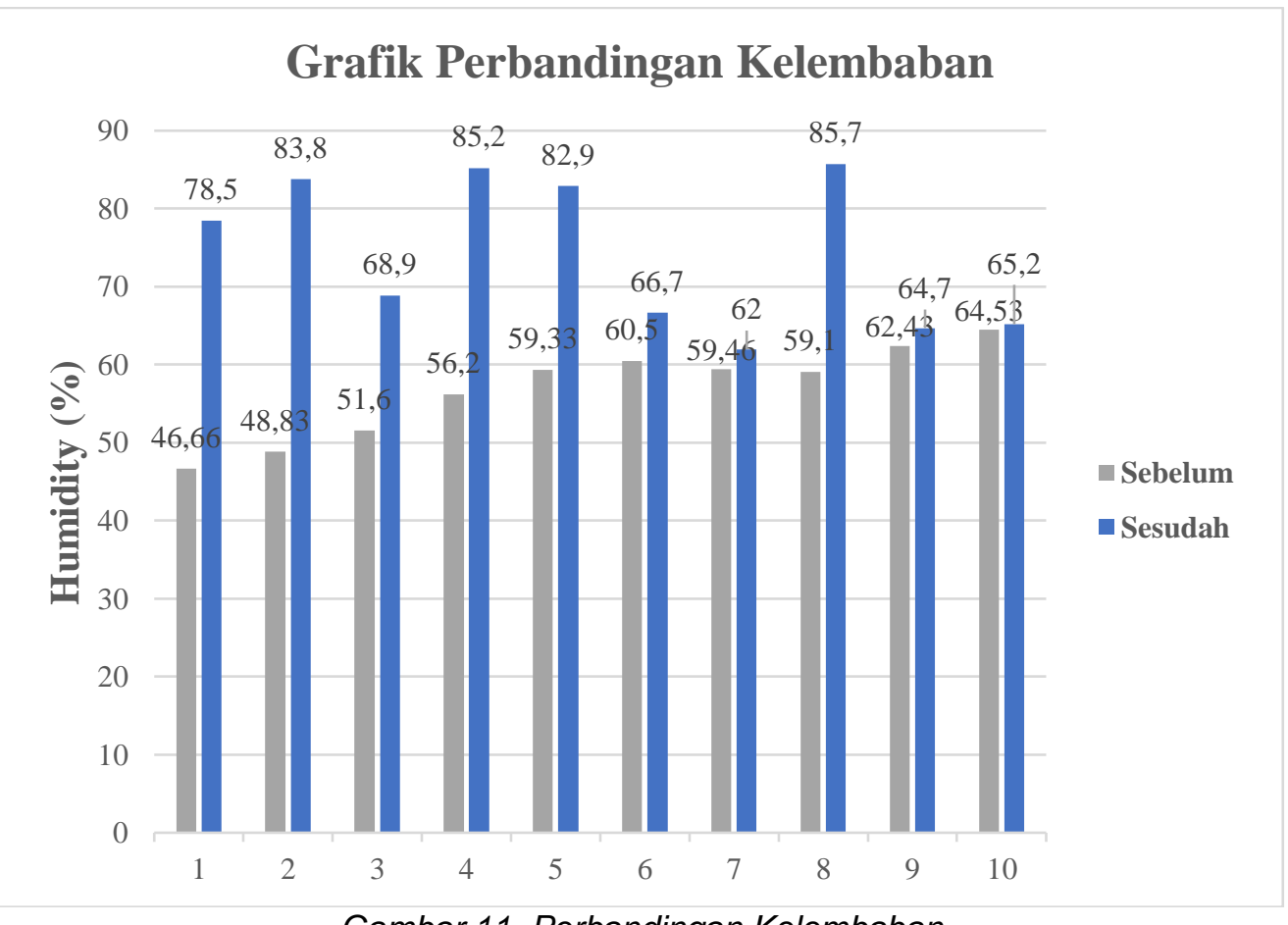

Gambar 11. Perbandingan Kelembaban

\subsubsection{Analisa Efektifitas Sistem terhadap Tanaman}

Sample tanaman yang digunakan untuk pengujian ini adalah 152 tanaman. Adapun parameter yang digunakan untuk menentukan efektifitas sistem terhadap tanaman ada 3 yaitu tanaman yang layu dan segar, tanaman kena titik air dan media tanam. 


\begin{tabular}{llc}
\hline No & Pengujian Perubahan Tanaman & Jumlah \\
\hline 1 & Tanaman Layu dan Segar \\
& $-\quad$ Tanaman Segar & 143 \\
& $-\quad$ Tanaman Layu & 9 \\
2 & Tanaman kena titik air & \\
& $-\quad$ Tanaman kena titik air & 143 \\
& $-\quad$ Tanaman tidak kena titik air & 9 \\
3 & Media Tanaman & \\
& $-\quad$ Media tanam basah & 140 \\
& - Media tanam kering & 12 \\
\hline
\end{tabular}

Berdasarkan Tabel 8 diperoleh hasil yang menggambarkan efektifitas sistem terhadap tanaman sesuai yang diharapkan. Berdasarkan hasil pengujian diperoleh tanaman layu sebanyak 9 tanaman, tanaman kena tidak kena titik ari 9 tanaman dan media tanaman kering 12 tanaman. Hal ini terjadi karena faktor alat penyiraman yang jaraknya berjauhan, serta dipengaruhi oleh adanya sirkulasi udara yang masuk melalui langit-langit di dekat atap dan fentilasi pada greenhouse.

\section{Kesimpulan}

Berdasarkan pembahasan tentang sistem pemantauan suhu, kelembaban serta pengendalian penyiraman secara otomatis pada tanaman aglaonema bahwa sistem telah mampu bekerja dengan baik, terlihat dari pengujian komponen dapat berjalan dengan baik, begitu juga ketika melakukan pengujian secara keseluruhan sistem yang dibangun dapat terintegrasi dengan baik antar komponen yang telah dirancang

Berdasarkan hasil implementasi sistem pemantaun suhu, kelembaban, serta pengendalian penyiraman secara otomatis pada tanaman aglaonema, maka dapat ditarik kesimpulan sebagai berikut:

1. Sistem dapat bekerja dengan baik sesuai dengan yang direncanakan.

2. Seluruh rangkain perangakat keras dapat terhubung sesuai yang diharapkan.

3. Pengujian suhu dapat bekerja dengan baik dimana margin error diperoleh sebesar $0.41^{\circ} \mathrm{C}$.

4. Pengujian kelembaban bekerja dengan baik, margin error diperoleh sebesar $2.56 \%$.

5. Web server dapat menampilkan data hasil sensor berupa suhu dan kelembaban yang ditampilkan dalam bentuk tabel dan grafik.

6. Pengujian penyiraman otomatis, pompa air menyala ketika melewati batas suhu maksimal dan batas kelembaban minimal. Sehingga pengujian dianggap berhasil.

7. Pengujian untuk mempertahankan suhu dan kelembaban ideal berhasil. Rata-rata suhu dan kelembaban ruangan sebelum menggunakan sistem yakni $30.2^{\circ} \mathrm{C}$ dan $56,86 \%$. Sedangkan rata-rata suhu dan kelembaban ruangan setelah menggunakan sistem yakni $27.85^{\circ} \mathrm{C}$ dan $73,99 \%$.

8. Pengujian menunjukkan bahwa terjadi penurunan rata-rata suhu sebesar $2.35^{\circ} \mathrm{C}$ dan kenaikan kelembaban sebesar $17.13 \%$.

\section{Referensi}

[1] Anita Tri Puspitasari. "Budidaya Tanaman Hias Aglaonema Di Deni Nursery And Gardening". Fakultas Petanian. Universitas Sebelas Maret Surakarta. 2010.

[2] Ari Purwanto. Aglaonema, Pesona Kecantikan Sang Ratu Daun. Kanisius. Yogyakarta. 2006.

[3] Bibit Bunga. http://bibitbunga.com/tanaman-hias-daun/tanaman-aglaonema. Diakses, 10 April 2017.

[4] Bernard T. Wahyu Wiryanta. Media Tanam untuk Tanaman Hias. Agro Media. Jakarta Selatan. 2008.

[5] Widyanti, Yustina Erna. Green house Rumah untuk Tanaman. Jakarta: PT. Penebar Swadaya. 1993.

[6] Jiang Xiao, Bei Jiang, Kan Jiang ming. "Design for Wireless Temperature and Humidity Monitoring System of the Intelligent Greenhouse". $2^{\text {nd }}$ International Conference on Computer Engineering and Technology, vol 3, v3-63, 2010. 
[7] H, Suhardiyanto. Teknologi Rumah Tanaman untuk Iklim Tropika Basah Pemodelan dan Pengendalian Lingkungan. Institut Pertanian Bogor. Press Bogor. Indonesia. 2009.

[8] Syafid, Ahmad. "Rancang Bangun Pengendali Suhu Pada Greenhouse Menggunakan Metode Fuzzy Sugeno". Teknik Informatika. Universitas Muhammadiyah Malang. 2016.

[9] Adafruit. https://cdn-shop.adafruit.com/datasheets/DHT22.pdf. Diakses, 10 April 2017.

[10] Oktovani, Yusuf. "Sistem Pengendalian Suhu dan Kelembaban Berbasis Wireless Embedded System". PTIIK. Universitas Brawijaya. 2013.

[11] I Madrap, Pushkar and A Deshmukh." PIC Microcontroller Based Greenhouse Monitoring and Contro System". International Journal of Advanced Research in Electrical, Electronics and Instrumentation Engineering, vol 5, Issue 9, 2016.

[12] Napitupulu, H. Modifikasi Control Auto Shrink Packaging Machine Menggunakan Smart Relay. 2010

[13] Margolis M. Arduino Cookbook. Published by O'Reilly Media, Inc., 1005. Gravenstein Highway North, Sebastopol, CA 95472. 2011.

[14] Sukaridhoto, Stritrusta ST. Ph.D. Buku Jaringan Komputer 1. Politeknik Elektronika Negeri Surabaya. Jawa Timur. 2014. 